\title{
Environmental and Economic Impacts of Lighting Highways Using Photo-Voltaic Panels
}

\section{Eng. Mohamed Saber Shahat ${ }^{1 *}$, Prof. Dr. Soliman M. Sharaf², Dr. Mohamed Edrees ${ }^{2}$, and Dr. Mohamed Abdelhalim ${ }^{3}$}

\author{
${ }^{1}$ New and Renewable Energy Authority (NREA) \\ 2 Faculty of Engineering, Helwan University, Cairo, Egypt \\ ${ }^{3}$ Head of Radiological Division, Nuclear and Radiological Regulatory Authority, Egypt
}

*Corresponding author: Engineer. M.S. Shahat; saber133@hotmail.com

\begin{abstract}
The renewable energy sources in power generation globally increases rapidly over time. This paper presents a novel technique of street lighting by using off-grid solar energy system. The electrical power is generated from solar panels at the day time and stored in batteries and consequently, discharged in the street lamps at night. The charging, discharging and their rates rate are controlled obviously by charger controller. Highway road is selected in this study. Several aspects are optimized in this study. Number of columns, columns types, lamp arms, columns distance and the backup storage limits are studied. The sizing of the individual solar stations in terms of economic and environmental feasibility are optimized. New power saving technique will apply advanced methods to reduce the storage capacity and power consumption to enhance the economic feasibility of the suggested system. In addition, the life time of storage batteries is increased. The most appropriate technique is selected in terms of economic and environmental feasibility by comparing all the different cases suggested in this study. Finally, the best case for solar street lighting project is compared to the normal or conventional system to show the economic and environmental potentiality of using renewable energy, especially solar energy. Experimental solar energy street lighting system with power saving is implemented in this study.
\end{abstract}

Keywords: Lighting; highways; solar energy; photo-voltaic panels; environmental.

\section{INTRODUCTION}

Renewable energy is energy that is generated from renewable resources, which are naturally replenished on a human's life, such as, solar, wind, biomass, waves, and geothermal heat. Renewable energy often provides energy in two important areas: electricity generation, thermal.

In this paper, street lighting is studied by solar energy. Small off-grid solar stations with storage batteries is equipped. The energy is stored during daylight hours by charging batteries that are charged by solar cells. During the night the light poles with LED lamps is supplied by the batteries. Optimization technique is performed to achieve the suitable unit of generating group. The optimization technique depending upon solar cell specifications, electric load (lamps), size of batteries, the cable specifications and length of cables. In addition, the charging and discharging regulation of batteries. The main objective of the study is to preserve the environment by generating electricity to illuminate the streets by using an energy source that is environmentally friendly and does not have any harmful emissions such as those produced by the traditional methods of generating electricity by fossil fuel.

The study also aims at the economic feasibility of using renewable energy sources in generating electricity and contributing to solving the energy crisis and lighting the highways in an ideal way to preserve the safety of citizens and reduce road accidents and incidents and raise the rate of security and safety.

\section{SOLAR LIGHTING SYSTEM DESCRIPTION}

The solar lighting system consists of solar panels, batteries, lighting lamps, charger controller and power transmission cables as shown in FIGURE 1.

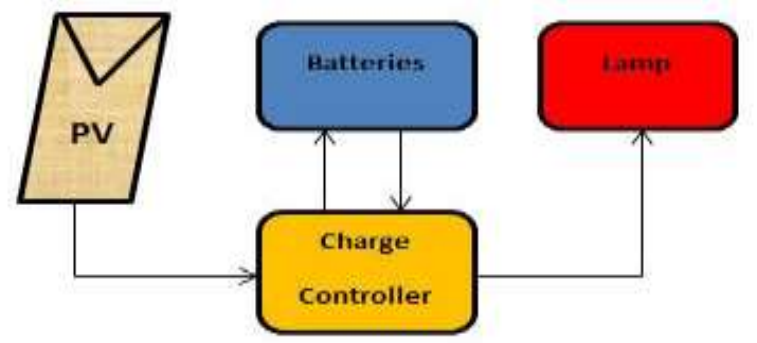

FIGURE 1: Block diagram of PV street lighting system

A solar cell, or photovoltaic cell, is an electrical device that converts the energy of light directly into electricity by the photovoltaic effect. Battery is an electrochemical device that converts chemical energy into electrical energy and electrical energy to chemical energy.

Lead acid batteries are the most commonly used type of battery in photovoltaic systems. Although lead acid batteries have a low energy density, only moderate efficiency and high maintenance requirements, they also have a long lifetime and low costs compared to other battery types [1]. 
Solar charge controllers are an integral part of any standalone solar system. Solar charge controllers work by regulating this voltage to a level that can safely charge batteries and run appliances.

A light-emitting diode (LED) is a two-lead semiconductor light source. It is a $\mathrm{p}-\mathrm{n}$ junction diode that emits light when activate.

\section{SOLAR HIGHWAYS STREET LIGHTING DESIGN}

It talks about the design of the system and choosing the road in which the study will be applied and choose the appropriate design for the distribution of columns on this road according to the standards.

\section{- Road Specifications}

The specifications of the suggested highway road are:

Two-way median with 8 meters' width each with two lanes with four meters' width for each lane. According to Egyptian standard code [2], the height of columns width of road. So, the column height nearly 8 meters. The distance between columns $=24$ to 32 meters with 100 watt led light [3] nearly 25 meters. Finally, the columns and lamps specifications are: 8 meters' height, 100 watt led lamp with 25 meters' distance between columns.

\section{- Batteries Calculations for One Lamp/Day}

Assume that the lamps work continuously within 13 hours, the maximum number of night hours at 24 volts, which is the battery voltage. One lamp consumes 100 watts when run from a nominal 24-volt battery, and then in one day the lamp will consume:

Power $\times$ time $=(100$ watts $) \times(13$ hours $)=1300 \mathrm{WH}$ of electrical energy.

The battery capacity, however, will be measured in ampere-hours (Ah). To determine the connected load in Ah for the lamp, simply divide the energy by the voltage. In this case,

the result is $=$ energy $\div$ voltage $=1300 \div 24=54.2 \mathrm{Ah}$

Practically there are losses in the battery charging value estimated at $10 \%$ and losses in the cables estimated at 2\%: [4]

From (3.3): Load/losses $=54.2 \div(0.9 \times 0.98)=61.5 A h(3.4)$

Consideration should be given to the cloudy days so that the batteries are not fully discharged, which affects their efficiency, and let them assume two days.

This means that a total capacity $=$ Days of autonomy $\mathrm{x}$ load after losses from (3.4) $=2$ days $x 61.5 \mathrm{AH}=122.8 \mathrm{Ah}$

At this point, a decision must be made as to what type of battery to use. System will allow deep discharge, suppose the battery (or batteries) is allowed to discharge to 20\% of full charge. This means that only $80 \%$ of the battery rating is available for use.

From (3.5) the capacity is = value of load after days of autonomy $\div$ DOD $=122.8 \div 0.8=153.5 \mathrm{Ah}$.

This capacity might be obtained with a single 24-volt, 153.5 Ah battery, but more likely would be obtained with two 12-volt batteries connected in series, since a 24volt with high amperes is difficult to found.

\section{Batteries Capacity (Ah) Formula}

Total Watt-hours per day x Days of autonomy $\div$ (Battery losses $\mathrm{x}$ cable losses $\mathrm{x}$ deep of discharger $\mathrm{x}$ nominal battery voltage).

Battery Capacity $(\mathrm{Ah})=$ Total Watt-hours per day $\mathrm{x}$ Days of autonomy $\div(0.9 \times 0.98 \times 0.8 \times$ nominal battery voltage 24 volts 3.7$)$

\section{- PV Panels Capacity}

To determine the capacity of solar panels, it must to determine the number of hours of solar brightness in Egypt, which is estimated at 6 hours in the worst cases in the winter season [5].

If a PV array with a nominal $24 \mathrm{~V}$ output is used, then the array must produce the needs of the batteries in ampere hours. However, it must be taken into consideration that the PV modules may not always operate at peak efficiency, such as if they get dusty. Operation at cell temperatures higher than $25 \mathrm{C}^{\circ}$ may reduce maximum output power by an additional $15 \%$ by reducing the module maximum power voltage by $15 \%$, Therefore 28 -volt (or more) solar panels will be choice, about $15 \%$ more than 24 - volts. In practice, the panels are designed with a voltage of 30 volts to compensate for the loss. But in calculations there are some losses on battery, cables and solar cells its value is estimated at $2 \%$

To calculate the solar panel capacity which needed in the system, first the Watt-hours per day for one lamp will be calculated then the Watt-hours per day will be divided by (losses $\mathrm{x}$ full sun hour) $=$ Watt-hours per day / $(0.8 \times 6)$ = Watt-hours per day/4.8 [6].

The lamp consuming 100 watts in 13 hours in one day, so it is consuming $1300 \mathrm{Wh}$ per days then then solar panel capacity $=1300 / 4.8=270$ watt.

Finally, one lamp theoretically needs one module capable of producing 270 watts, Therefore, solar panels (poly crystalline because it is simpler and costs less) with a 270 watt will be chosen due to its availability and accessibility in the local market.

\section{- MPPT Charge Controller}

Charging controller is a power electronics device used to perform the Maximum Power Point Tracker (MPPT), which increases the efficiency of the system effectively, is used here. By using it, the system always operates at its Maximum Power Point (MPP), thereby producing its maximum power output. Thus, an MPPT maximizes efficiency of the solar station

Each solar cell has its own point the current (I) and the voltage (V) of the cell, as a result of Provide the maximum energy output for the panel., FIGURE 2 shows I$\mathrm{V}$ curve of a PV panel. Also, power-voltage curve is shown in the figure. The maximum power condition is shown in the top of the power-voltage curve (PMPP). In the system design the charge controller will be MPPT type with $125 \%$ of PV capacity. [7]

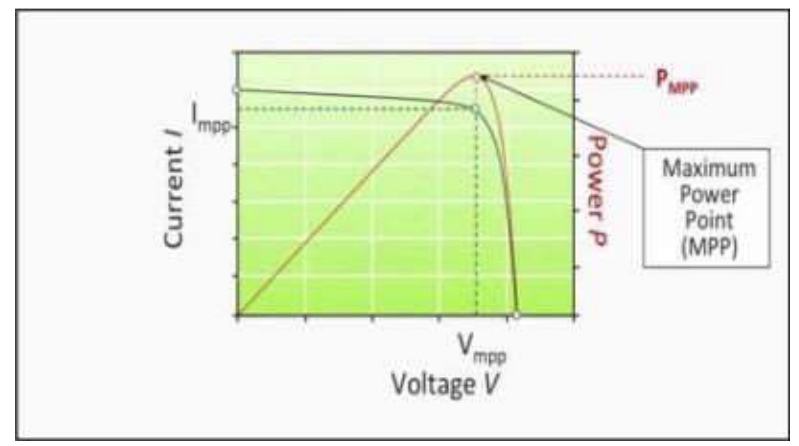

FIGURE 2: MPPT IV versus PV Curve

Note. In the system design the charge controller will be MPPT type with $125 \%$ of PV capacity [8]. 


\section{- Cables}

The Formula If its need to calculate the voltage drop under a given set of circumstances, there is a formula by which it can be determined.

Let: $\mathrm{A}=$ cross sectional area of cable in $\left(\mathrm{mm}^{2}\right)$

$L=$ route length in meters for one conductor only

I wire $=$ current measured in amps

$\rho=$ electrical resistivity of cable $\left(\left(\mathrm{ohm} \times \mathrm{mm}^{2} / \mathrm{m}\right.\right.$ (also $\left.\left.\Omega \times \mathrm{m}\right)\right)$

Electrical resistivity of copper $=0.017$, aluminum $=0.028$, steel $=0.18[9]$

$V \operatorname{drop}(V)=2 \times L(m) \times I$ wire $(A) \times \rho / A$

The max value of voltage drop must not be more than $4 \%$ of the nominal voltage which $=24$ volt, the value of $3 \%$ will be chosen as a safety factor [10]

To find the cross-sectional area of cable under voltage drop $=0.03 \times 24$ volt $=0.72$ volt so, the voltage drop $=$ 0.75 volt as accepted value in the calculations. From the formula:

$A=2 \times L \times I_{\text {wire }} \times \rho \div 0.75$

For one lamp 100 watt and 24 volt the current $=4.2 \mathrm{AMP}$ Take the current $=5 \mathrm{Amp}$

Copper cables would be chosen because they have low resistance and high conductivity.

For the design calculations:

$\mathrm{A}=(2 \times 5 \times 0.017 \div 0.75) L$

\section{OPTIMIZATION STUDY OF THE ENERGY STATIONS}

The study will be carried out at the beginning on the normal case, which is that each column is an independent unit. Then the study will have extended to several groups of columns together supplied from an energy station. Several cases are suggested for this study which are consist of 4, 6, 8, 10, and 20 columns for an energy station.
In the case of the group consisting of 4 columns, the study was done on one side of the road and on two sides, and it was found that in the case of the presence of the columns on both sides of the road, it more economic in the length of the cables and its cross section area, so the study will in all cases be on both sides of the road.

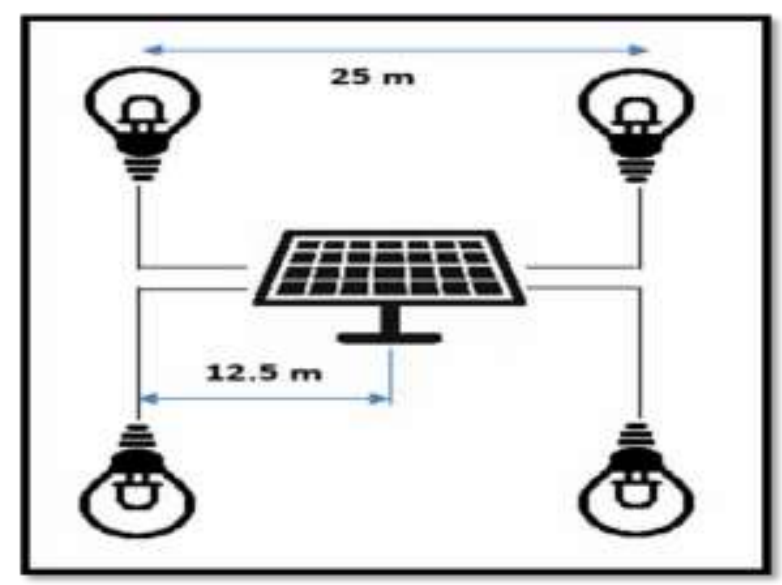

FIGURE 3: Four columns in both directions on the road

At the end of each case study there will be a generalization of this condition at a distance of $1 \mathrm{~km}$ to find out the total number of batteries, solar panels, charging controllers, cable length and cross section areas of cables used in the system. Comparison between all the cases studied is highlighted and the best cases will be selected in terms of economic and environmental efficiency. TABLE 1 shows the comparison results for different cases.

A comparison is made between all cases through the main components of the system, namely batteries, solar panels and cables, which create economic differences due to their high prices and environmental impacts, especially solar panels and batteries, so reducing their numbers will raise the economic and environmental feasibility.

TABLE 1: Final results of the cases (along 1 KM distance USING 100A battery 270W Solar panel)

\begin{tabular}{|c|c|c|c|c|c|c|c|c|c|}
\hline $\begin{array}{c}\text { No. of } \\
\text { column }\end{array}$ & $\begin{array}{c}\text { No. of } \\
\text { stations }\end{array}$ & $\begin{array}{c}\text { No. of } \\
\text { batteries }\end{array}$ & $\begin{array}{c}\text { No. of } \\
\mathbf{P V} \\
\text { panel }\end{array}$ & $\begin{array}{c}\text { Charge } \\
\text { controller }\end{array}$ & $\begin{array}{c}\mathbf{4} \mathbf{~ m m}^{\mathbf{2}} \\
\mathbf{c a b l e}\end{array}$ & $\begin{array}{c}\mathbf{6} \mathbf{~ m m}^{\mathbf{2}} \\
\mathbf{c a b l e}\end{array}$ & $\begin{array}{c}\mathbf{1 0} \mathbf{~ m m}^{\mathbf{2}} \\
\mathbf{c a b l e}\end{array}$ & $\begin{array}{c}\mathbf{1 6} \mathbf{~ m m}^{\mathbf{2}} \\
\mathbf{c a b l e}\end{array}$ & $\begin{array}{c}\mathbf{2 5} \mathbf{~ m m}^{\mathbf{2}} \\
\mathbf{c a b l e}\end{array}$ \\
\hline 1 & 80 & 320 & 80 & $80,12 \mathrm{~A}$ & $960 \mathrm{~m}$ & - & - & - & - \\
\hline 4 & 20 & 280 & 80 & $20,50 \mathrm{~A}$ & - & $2600 \mathrm{~m}$ & - & - & - \\
\hline 6 & 13 & 266 & 80 & $13,75 \mathrm{~A}$ & $532 \mathrm{~m}$ & - & $2394 \mathrm{~m}$ & - & - \\
\hline 8 & 10 & 260 & 80 & $10,100 \mathrm{~A}$ & - & $1300 \mathrm{~m}$ & $2300 \mathrm{~m}$ & - & - \\
\hline 10 & 8 & 256 & 80 & $8,125 \mathrm{~A}$ & $320 \mathrm{~m}$ & - & $1440 \mathrm{~m}$ & $2240 \mathrm{~m}$ & - \\
\hline 20 & 4 & 248 & 80 & $4,250 \mathrm{~A}$ & - & $520 \mathrm{~m}$ & $920 \mathrm{~m}$ & $1320 \mathrm{~m}$ & $3840 \mathrm{~m}$ \\
\hline
\end{tabular}

According to the Egyptian market in 2021 the average of price of:

1. $100 \mathrm{~A} 12 \mathrm{~V}$ solar battery $=2500 \mathrm{~L} . \mathrm{E}$

2. 1-watt solar PV (poly crystalline) $=7$ L.E

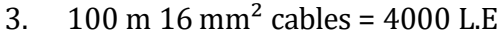

4. $100 \mathrm{~m} 10 \mathrm{~mm}^{2}$ cables $=2500$ L.E

5. $100 \mathrm{~m}^{6} \mathrm{~mm}^{2}$ cables $=1200$ L.E

6. $100 \mathrm{~m}^{4} \mathrm{~mm}^{2}$ cables $=1000$ L.E

7. 24 V DC 100 -watt LED lamp $=2000$ L.E 
TABLE 2A: Total cost of the stations (along 1 KM distance USING 100A battery 270W Solar panel and 100W LED)

\begin{tabular}{|c|c|c|c|c|c|}
\hline No. of station & Batteries cost & PV panel cost & LED lamps cost & Cable cost & Total cost \\
\hline 1 & 800000 & 151200 & 160000 & 3,500 & $1,120,800 \mathrm{LE}$ \\
\hline 4 & 700000 & 151200 & 160000 & 26,000 & $1,048,400 \mathrm{LE}$ \\
\hline 6 & 665000 & 151200 & 160000 & 31,000 & $1,041,370 \mathrm{LE}$ \\
\hline 8 & 650000 & 151200 & 160000 & 70,000 & $1,034,300 \mathrm{LE}$ \\
\hline 10 & 640000 & 151200 & 160000 & 101,000 & $1,080,000 \mathrm{LE}$ \\
\hline
\end{tabular}

The case of 20 columns is neglected due to the costs of cable is very high, so the total cost is higher than any cases and from TABLE $2 A$ the best three cases are 4,6,8 columns and it will be redesigned after energy saving.

\section{ENERGY SAVING AND ECONOMIC BENEFITS}

The energy saving study will be applied by reducing the intensity of the lighting by half in the late hours of the night by an electronic circuit will explain in the experimental and then recalculate again after applying power saving to reach the best case for practical application after calculate the total price.

\section{- Best Case for Final Application}

After the applying power saving on the best three cases and through the results in the TABLE $2 \mathrm{~B}$ which shows there are a different between cases in number of batteries, and cable length and its cross-section area. Then, the total price for each case in a length of $1 \mathrm{~km}$ is calculated at the Egyptian market prices to reach the best case for the final application as shown in TABLE 3

TABLE 2B: Final result of three best cases after power saving

\begin{tabular}{|c|c|c|c|c|c|c|c|c|}
\hline $\begin{array}{c}\text { No. of } \\
\text { column }\end{array}$ & $\begin{array}{c}\text { No. of } \\
\text { stations }\end{array}$ & $\begin{array}{c}\text { No. of } \\
\text { batteries }\end{array}$ & $\begin{array}{c}\text { No. of } \\
\text { LED lamps }\end{array}$ & $\begin{array}{c}\text { No. of } \\
\text { PV CELL }\end{array}$ & $\begin{array}{c}\text { Charge } \\
\text { controller }\end{array}$ & $\begin{array}{c}\mathbf{4} \mathbf{~ m m}^{\mathbf{2}} \\
\text { cable }\end{array}$ & $\begin{array}{c}\mathbf{6} \mathbf{~ m m}^{\mathbf{2}} \\
\text { cable }\end{array}$ & $\begin{array}{c}\mathbf{1 0}_{\mathbf{~ m m}}^{\mathbf{2}} \\
\text { cable }\end{array}$ \\
\hline 4 & 20 & 200 & 80 & 80 & $20,45 \mathrm{~A}$ & - & $2600 \mathrm{~m}$ & - \\
\hline 6 & 13 & 186 & 80 & 80 & $13,60 \mathrm{~A}$ & $532 \mathrm{~m}$ & - & $2394 \mathrm{~m}$ \\
\hline 8 & 10 & 200 & 80 & 80 & $10,77 \mathrm{~A}$ & - & $1300 \mathrm{~m}$ & $2300 \mathrm{~m}$ \\
\hline
\end{tabular}

TABLE 3: Final cost of component (batteries, PV panels, LED lamps, cable) of the best three stations along $1 \mathrm{KM}$

\begin{tabular}{|c|c|c|c|}
\hline Station & 4 columns & 6 columns & 8 columns \\
\hline 270w A $30 \mathrm{~V}$ panels.7 L.E for 1 watt & $270 \times 7 \times 80=151,200$ & $270 \times 7 \times 80=151,200$ & $270 \times 7 \times 08=151,200$ \\
\hline 100 A 12 V batteries 2,500 L.E for battery & $200 \times 2,500=500,000$ & $186 \times 2,500=465,000$ & $200 \times 2,500=500,000$ \\
\hline 24 V 100-watt LED lamp 2,000 L.E for lamp & $80 \times 2000=160,000$ & $80 \times 2000=160,000$ & $80 \times 2000=160,000$ \\
\hline $100 \mathrm{~m} 10 \mathrm{~mm}^{2}$ cable,2,500 L.E for $\mathbf{1 0 0 m}$ & - & $2500 \times 23.94=59,850$ & $2500 \times 13=32,500$ \\
\hline $100 \mathrm{~m} \mathrm{~mm}^{2}$ cables,1,200 L.E for $\mathbf{1 0 0 m}$ & $1200 \times 26=31200$ & - & $1200 \times 23=27,600$ \\
\hline $100 \mathrm{~m} 4 \mathrm{~mm}^{2}$ cables, $\mathbf{1 , 0 0 0}$ L.E for $\mathbf{1 0 0 m}$ & - & $1000 \times 5.3=5,300$ & - \\
\hline Charge controller & $20 \times 3,000=60,000$ & $13 \times 3,500=46,000$ & $10 \times 4500=45,000$ \\
\hline Columns & $80 \times 2000=160,000$ & $80 \times 2000=160,000$ & $80 \times 2000=160,000$ \\
\hline Power saving control circuit & $4 \times 3000=12,000$ & $6 \times 3000=18,000$ & $8 \times 3000=24,000$ \\
\hline TOTAL COST & $1,074,400$ L. E & $1,065,350$ L. E & $1,100,300$ L. E \\
\hline
\end{tabular}

After total price calculations it's appear that Cases of 4 \& 6 columns more economical than case of 8 columns, But It is noted that the total cost of $4 \& 6$ columns is close to each other, but choosing the second case ( 6 columns) is better economically than the first case because the number of batteries in the second case is less and this helps to reduce the cost of maintenance in the future as the batteries are changed every 5 years.
- Traditional Method Cost at the same road

At the same conditions of case study and the standard of street lighting the lamps wattage $=250 \mathrm{watt}$ HPS and the cable diameter $=10 \mathrm{~mm}^{2}$ [3]. According to the Egyptian market the average of 250watt HPS spotlight $=1300$ L.E (lamp + bulb) and $100 \mathrm{~m} 10 \mathrm{~mm}^{2}$ cables $=2500 \mathrm{~L} . \mathrm{E}$ 
For the same road conditions along $1 \mathrm{KM}$ :

TABLE 4: Final cost of the system

\begin{tabular}{|l|c|c|c|}
\hline Item & Technical & Number & Price \\
\hline lamps & 250 watt HPS & 80 & 1300 L.E x $80=104,000$ L. E \\
\hline cables & $10 \mathrm{~mm}^{2}$ & $1000 \mathrm{~m}$ & $2,500 \times 10=25,000$ L. E \\
\hline columns & $\begin{array}{c}\text { Commonly used in street } \\
\text { lighting }\end{array}$ & 80 & $2,000 \times 80=160,000$ \\
\hline \multicolumn{2}{|c|}{ Total price of lamps and cables (initial cost) } \\
\hline
\end{tabular}

The total consumptions of power in one day $=250 \times 80$ columns $\times 13$ hours $=260 \mathrm{KW} /$ day, according Government Tariff the Price of $1 \mathrm{KW}=1.50 \mathrm{~L}$. E, so the total price of the power consumptions in the day $=260 \times 1.50=390 \mathrm{~L} . \mathrm{E}$

The total consumptions of power in one day $=250 \times 80$ columns $\times 13$ hours $=260 \mathrm{KW} /$ day, according Government Tariff the Price of $1 \mathrm{KW}=1.50 \mathrm{~L}$. E, so the total price of the power consumptions in the day $=260 \times 1.50=390$ L.E

From lamps specification the average life time of HPS lamps is 5 years, so the total cost of the traditional street lighting in 5 years =initial cost of lamps and cables+ Power consumption + Lamps cost after 5 years' maintenance, taking into account the increase in the electricity price and the inflation rate. The total consumption in 5 years $=260$ $\mathrm{kw} /$ day $\times 366 \times 5=475,800 \mathrm{kw}$
The initial cost shows that the traditional method of street lighting is more economical than solar street lighting in this case study, and by adding an annual increase of $5 \%$ as an average for global inflation on the value of the components that will be changed in the maintenance process (batteries - HPS lamps - LED bulbs). And through the reports of the Ministry of Electricity and Renewable Energy, it appears that the kilowatt-hour price for street lighting in 2009 was approximately 0.41 pounds, and in 2020 the price reached approximately 1.5 , meaning that the annual increase is about 0.1 pounds. With the accumulation of years and energy consumption as shown in TABLE 5 and FIGURE 4, it appears that the solar street lighting system is more economical than traditional street lighting.

TABLE 5: Comparison between accumulative costs of two systems

\begin{tabular}{|c|c|c|}
\hline System & Traditional & Solar \\
\hline Initial cost & 289,000 L. E & 1,065,350 L. E \\
\hline After 5 years & $\begin{array}{c}\text { Lamps + power consumption }=30,000+951,600 \\
+ \text { initial cost }(289,000)=\mathbf{1}, \mathbf{2 7 9 , 0 0 0 ~ L E ~}\end{array}$ & $\begin{array}{l}\text { Batteries }+ \text { initial cost }=581,250 \\
\quad+1,065,350=\mathbf{1}, \mathbf{6 4 6 , 6 0 0}\end{array}$ \\
\hline After 10 years & $\begin{array}{c}\text { Lamps }+ \text { power consumption }=37,500+ \\
1,189,500+5 \text { years total costs }(1,279,000 \mathrm{LE})= \\
\mathbf{2 , 5 0 6 , 0 0 0 ~} \mathbf{L E}\end{array}$ & $\begin{array}{l}\text { Batteries }+5 \text { years total costs }= \\
1,646,600+726,562=2,373,162\end{array}$ \\
\hline After 15 years & $\begin{array}{c}\text { Lamps }+ \text { power consumption }=46,875 \\
+1,427,400+10 \text { yeas total costs }(2,506,000 \mathrm{LE})= \\
\mathbf{4 , 3 9 4 , 2 7 5} \mathbf{L E}\end{array}$ & $\begin{array}{c}\text { Batteries + LED lamps+ } 10 \text { years' } \\
\text { total costs }=280,000+ \\
908,202+2,373,162=\mathbf{3 , 5 6 1}, \mathbf{1 6 2}\end{array}$ \\
\hline After 20 years & $\begin{array}{c}\text { Lamps + power consumption }=58,593+ \\
1,665,300+15 \text { years total cost }(4,394,275 \mathrm{LE})= \\
\mathbf{6 , 1 1 8 , 1 6 8} \mathbf{L E}\end{array}$ & $\begin{array}{c}\text { Batteries }+15 \text { years' total costs }= \\
1,135,252+3,561,162= \\
\mathbf{4 , 6 9 6 , \mathbf { 4 1 4 }} \\
\end{array}$ \\
\hline After 25 years & $\begin{array}{c}\text { Lamps + power consumption }=73,240+ \\
1,903,200+20 \text { years total cost }(6,118,168 \mathrm{LE})= \\
\mathbf{8 , 0 9 4 , 6 0 8 ~} \mathbf{~ E E}\end{array}$ & $\begin{array}{c}\text { Batteries + solar cells }+20 \text { years total } \\
\text { costs }=1,419,065+339,750+ \\
4,696,414=\mathbf{6 , 4 5 5 , 2 2 9}\end{array}$ \\
\hline
\end{tabular}

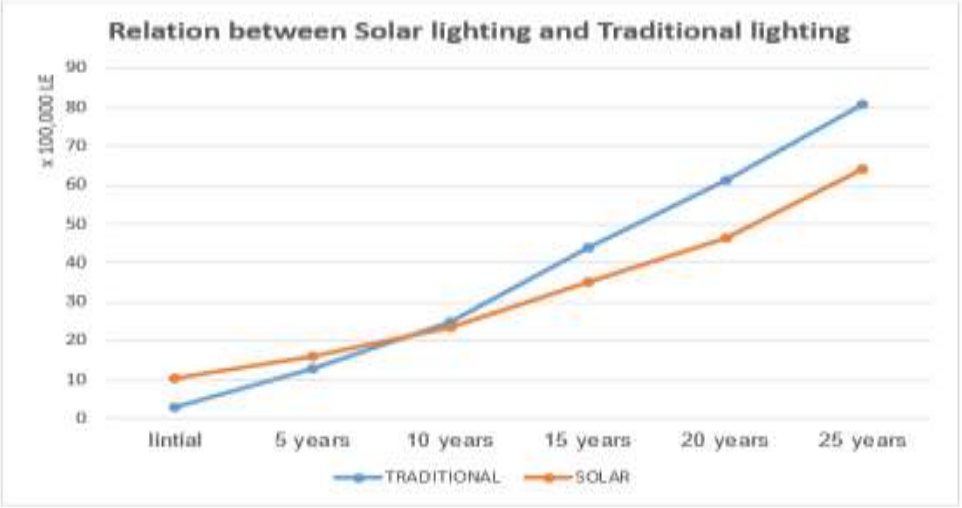

FIGURE 4: A graph showing the relation between traditional lighting and solar lighting 


\section{SOLAR ENERGY AND ENVIRONMENTAL}

Solar energy is one of the best ways to generate clean energy that does not harm the environment. Solar energy is most commonly exploited in three ways, Photovoltaic systems for electricity generation; Solar thermal power plants to obtain electricity and heat; and Solar thermal systems - for thermal energy.

The major advantage of solar power is that no pollution is created in the process of generating electricity. Environmentally it the cleanest and Green energy. Solar Energy is clean, renewable (unlike gas, oil and coal) and sustainable, helping to protect our environment. It does not contribute to global warming, acid rain or smog. It actively contributes to the decrease of harmful greenhouse gas emissions.

Positive effects of solar power plants are far more significant than the negative ones. In PV electricity generation, there are no $\mathrm{CO} 2$ and greenhouse gas emissions, nitrogen oxide, sulfur dioxide or mercury into the atmosphere like many traditional forms of electrical generation does. During power plant operation, there is neither emission of particles that cause respiratory problems in humans and animals nor emission of heavy metals such as lead $(\mathrm{Pb})$. It doesn't have noise and movement during operation. When comparing emissions from different power plants; it is clear that PV plants are much less than others, as shown in FIGURE 5 [12].

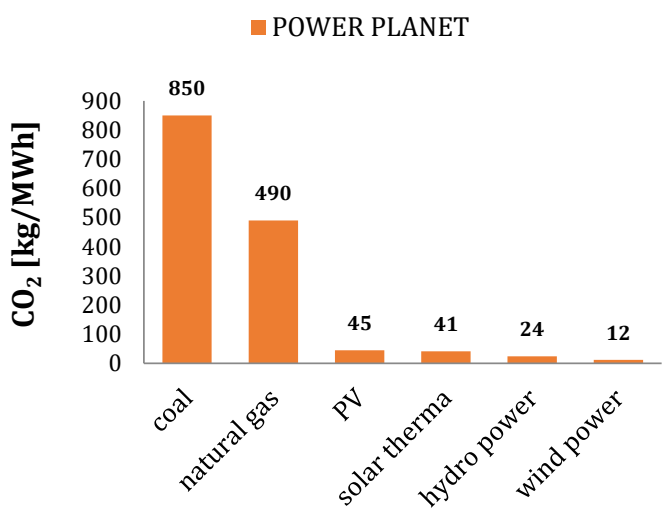

FIGURE 5: Specific emissions of carbon dioxide $\left(\mathrm{CO}_{2}\right)$ for different plant.

\section{EXPERIMENTAL OF MAKING SOLAR STREET LIGHTING SYSTEM WITH POWER SAVING}

It will be a simulation of the best choice for the solar station, which will feed the number of 6 lighting columns and applied energy saving system on it through a simple electronic circuit that reduces the voltage, which in turn reduces the energy consumed by the batteries, which reduces their number.

As shown in block diagram FIGURE 6A \& 6B the system consisting of:

a-Simple electronic circuit (P.S circuit)

- $\mathrm{T} 1, \mathrm{~T} 2, \mathrm{~T} 3$ on delay timers

- T4 pulse delay timer

- R1, R2, R3 4 contact 6A relays

- 1 photo cell sensor (P.C) or Selector

b- 2 batteries with 12 volts (Battery bank)

c- 2 Solar panels 14 volts

d- 6 led lamps with 24 volts

e- Charge controller

f- Connection box and cables
A

B
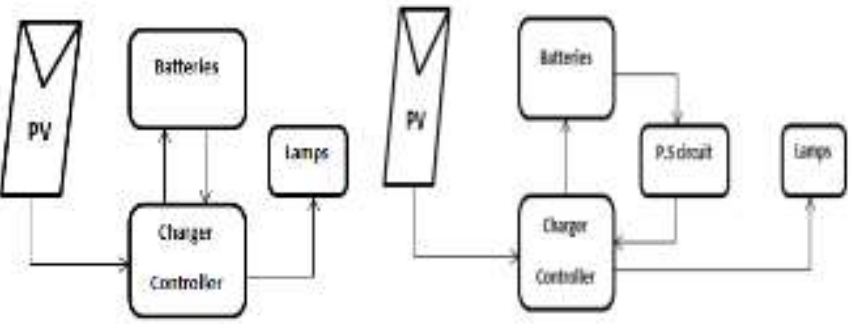

FIGURE 6A: Block diagram of the normal system

FIGURE 6B: block diagram of the system with power saving

It's a simple electronic circuit as shown in FIGURE 7A and $7 \mathrm{~B}$ consisting of timers and relays and automatic switches that regulate the connection of the batteries to the charger controller; it works in the initial period on all the batteries. The second period is divided into two stages, first the system work on the half number of the batteries to minimize the volt into 12 volts then the circuit switch to choose the other half of the batteries with the 12 volts also. From FIGURE 7A \& 7B:

- Timer 1(T1) to control full power time.

- Timer 2(T2) to control batteries 1 half power time.

- Timer 3(T3) to control batteries 1 half power time.

- Timer 4(T4) pulse delay time to regulate charge controller volts

1) In the first step: the photo cell sensor OR selector switch start to connect wire no.1 and wire no.2 in fig 11.2. $\mathrm{T}_{1}$ now has a signal and it is active and $\mathrm{T}_{2}, \mathrm{~T}_{3}$ are off and R2, R3 are activate too and R1 is off, because of when $\mathrm{R}_{2}$ is activate then $\mathrm{T} 4$ is deactivate so in this case all batteries are work with 24 volts.

2) In the second step: after $\mathrm{T} 1$ finished its time then $\mathrm{T} 2$ is activate and R2 is deactivate then R3 will be deactivate for 1 second only to reset the charge controller to recognize 12 -volt dc without alarms.

Note: in case of charge controller which used in this circuit only one volt will be recognize for it (24 or12) So there is a pulse delay timer make reset for it to change its setting. In this case, batteries 1 only work.

3) In the third step: after $T_{2}$ finished its time then $T_{3}$ is activate and $\mathrm{R} 1$ is activate too (there is a contact from $\mathrm{R}_{1}$ to $\mathrm{R} 2$ ) then $\mathrm{R} 2$ is activate and $\mathrm{R} 3$ is connect. In this case, batteries 2 only work.

In the final step: after T3 finished its time and it disconnects all system until it starts again with selector or photo cell.

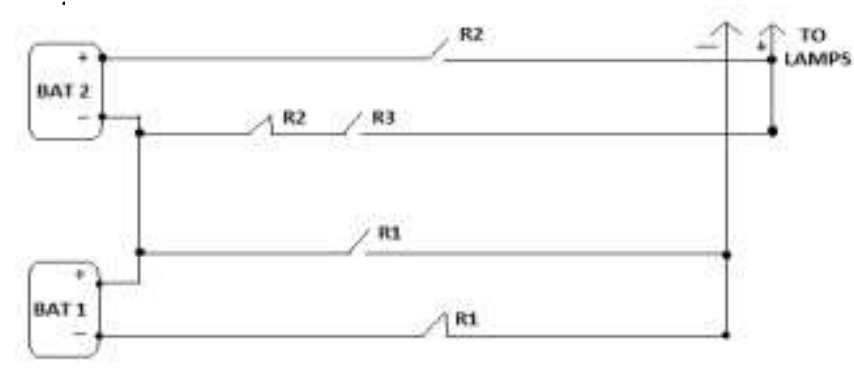

FIGURE 7A: Power circuit of power saving 


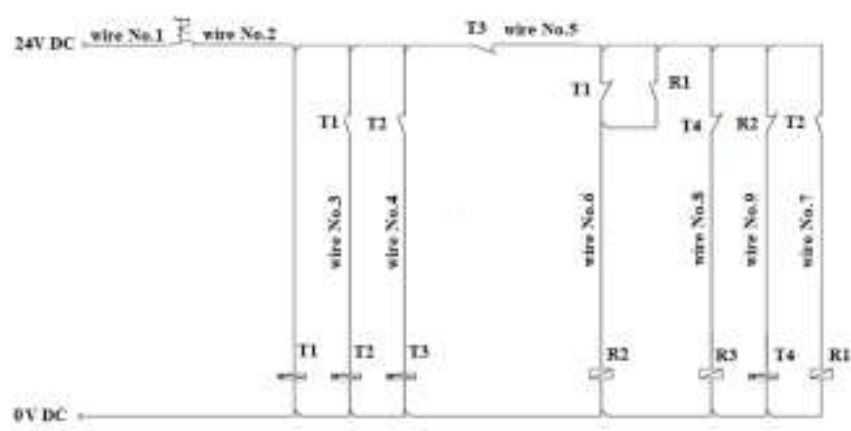

FIGURE 7B: Control circuit of power saving

\section{CONCLUSION}

This thesis work was devoted to solar street lighting systems. The main purpose of the study was to make small stations for solar street lighting instead of having each column as a separate unit, then reaching the optimal number of columns when installing several factors to show that small stations are more economical than each individual column. This study included how to design street lighting systems and know the appropriate lighting intensity according to the type of street to be applied to the study and also included how to design standalone solar stations and how to calculate the capacity of solar panels, the capacity of batteries, cable length and sections. After reaching the best cases according to the case study, the idea of energy saving by electronic circuit was applied, this reduces the lighting in half in the late periods of the night to reach the best case.

\section{REFERENCE}

[1] An Overview of Batteries for Photovoltaic (PV) source International Journal of Computer Applications November 2013

[2] "Egyptian code for lighting design وشروط وتنفيذ أعدال الصبانة "الكود الدصري ألس تصمير "No.308 for 2006

[3] "International Journal of Scientific Engineering and Technology Research" Volume.03, IssueNo.17, August2014, Pages: 3518-3522 BY: NAN SU MON AUNG, ZAW HTET MYINT
[4] "Photovoltaic systems engineering" by "Roger A. Messenger Jerry Ventre" second edition 2005 P 49

[5] Hours of full sun Egypt "the solar atlas of Egypt"

[6] "Photovoltaic systems engineering" by "Roger A. Messenger Jerry Ventre" second edition 2005 "Chapter 4 PV System Examples" P 115

[7] "Designing and Implementation of Maximum Power Point Tracking (MPPT) Solar Charge Controller" 2017 International Conference on Nascent Technologies in the Engineering Field (ICNTE-2017) by: Mihir Pathare \& Vimith Shetty

[8] "Photovoltaic systems engineering" by "Roger A. Messenger Jerry Ventre" second edition 2005 chapter 4, P 115

[9] "Rainbow power company" solar specialist organization in Australia cable design "Wire Charts" https://www.rpc.com.au/services/downloads.html?m odels $=\mathrm{W}$

[10] "Droop Voltage Range Design in DC Micro-Grids Considering Cable Resistance"

By: Fang Chen, Wei Zhang, Rolando Burgos and Dushan Boroyevich "Centre for Power Electronics Systems (CPES)" "Virginia Polytechnic Institute \& State University Blacksburg, VA, US

[11] "Report of the Ministry of Electricity and Renewable Energy " governmental report from Ministry of Electricity and Renewable Energy data base "2018 edition" page:79

[12] "Energy Systems (Resources and resource availability)" chapter 7 by: Kirit Parikh (India), Jim Seka (UK) \& "International Atomic Energy Agency, World Energy Outlook 2009 - GLOBAL ENERGY TRENDS TO 2030 [Online], 2009 [cited August 1, 2010]" ;page: http://energyforhumanity.org/briefings/carbonemissions/lifecycle-carbon-emissions-of-electricitygeneration-sources/ 